\title{
Release and Discharge Sebagai Bentuk Tanggung Jawab Pribadi Pemegang Saham Utang BLBI
}

\author{
Devi Andani \\ pascasarjanahukum.uii.ac.id
}

\begin{abstract}
This study aimed to identify the legal strength and legal consequences of release and discharge in MSAA and MRNIA as a form of personal responsibility of Bank Indonesia Liquidity Assistance (BLBI) debt shareholders. This qualitative research followed the typology of normative legal research. The study used a conceptual approach by examining the concept of MSAA and MRNIA agreements in which a Release and Discharge clause was found. The research data was collected by means of library research and documents. All the data obtained was then evaluated using the theory of Piercing the Corporate Veil, written descriptively, and analyzed qualitatively. The results showed that formally the Release and Discharge clause in MSAA and MRNIA had the legal strength though not materially. Then the legal consequences of Release and Discharge in MSAA and MRNIA for shareholders towards BLBI debt could be personally accounted for.
\end{abstract}

Keywords: Release and discharge; MSAA and MRNIA; personal responsibility of shareholders; BLBI

\begin{abstract}
Abstrak
Studi ini bertujuan untuk mengetahui kekuatan hukum serta akibat hukum release and discharge dalam MSAA dan MRNIA sebagai bentuk tanggung jawab pribadi pemegang saham utang BLBI. Penelitian ini termasuk jenis penelitian kualitatif dengan mengikuti tipologi penelitian hukum normatif. Penelitian ini menggunakan pendekatan konseptual, yaitu dengan cara mengkaji konsep perjanjian MSAA dan MRNIA yang di dalamnya terdapat klausula Release and Discharge. Data penelitian dikumpulkan dengan cara studi pustaka dan dokumen. Kemudian seluruh data yang diperoleh dari studi kepustakaan dan studi dokumen tersebut direlevansikan dengan teori Piercing the Corporate Veil serta dituliskan secara deskriptif dan dianalisa secara kualitatif. Hasil studi ini menunjukkan bahwa secara formal klausula Release and Discharge dalam MSAA dan MRNIA memiliki kekuatan hukum, namun secara material tidak. Kemudian akibat hukum Release and Discharge dalam MSAA dan MRNIA bagi pemegang saham dapat dimintakan pertanggungjawaban secara pribadi terhadap utang $\mathrm{BLBI}$
\end{abstract}

Kata-kata Kunci: Release and discharge; MSAA dan MRNIA; tanggung jawab pribadi pemegang saham; BLBI 


\section{Inx Renaissance No. 1 VOL. 3 JANUARI 2018: 1 - 24}

\section{Pendahuluan}

Krisis moneter pada Juli 1997 yang kemudian berlanjut terhadap krisis multidimensional, mendorong Indonesia untuk meminta bantuan Dana Moneter International (IMF). Atas usul IMF sebagai bagian dari reformasi perbankan, pada 1 November 1997, pemerintah harus mencabut izin usaha enam belas bank swasta nasional. Upaya ini dimaksudkan untuk memulihkan kepercayaan masyarakat terhadap perbankan, tetapi dalam kenyataannya justru menyebabkan masyarakat makin tidak percaya terhadap perbankan nasional. Terjadi penarikan secara besarbesaran (rush) terhadap bank-bank tidak sehat dan bank-bank sehat. Kemudian dalam waktu yang singkat, bank yang semula sehat karena efek domino beralih status menjadi bank sakit karena kesulitan likuiditas. ${ }^{1}$ Pada 3 September 1997, sejalan dengan kebijakan pemerintah, Bank Indonesia (BI) harus menjalankan perannya sebagai lender of last resort (fungsi BI sebagai bank sentral dalam upaya terakhir untuk meminjam uang). BI kemudian menyalurkan Bantuan Likuiditas Bank Indonesia (BLBI) kepada 48 bank yang mengalami kesulitan likuiditas sebesar Rp. 144.500.000.000.000.000,00. Ketika rush sudah berhenti, bank-bank penerima BLBI tersebut menghadapi persoalan baru yaitu berkaitan dengan kewajiban untuk mengembalikan atau melunasi utang BLBI tersebut. ${ }^{2}$

Penyelesaian utang BLBI yang dilakukan pemerintah melalui instrumen hukum secara keperdataan, baik melalui berbagai kebijakan Komite Kebijakan Sektor Keuangan (KKSK) maupun Badan Penyehatan Perbankan Nasional (BPPN) memilih cara penyelesaian di luar pengadilan. Kebijakan tersebut lebih didasarkan akan perlunya pengembalian atau pelunasan utang BLBI kepada negara. Meskipun terdapat penyalahgunaan penggunaan utang BLBI seperti dalam hal Bank Modern ${ }^{3}$ dan pelanggaran Batas Maksimum Pemberian Kredit (BMPK) seperti dalam hal Bank Dagang Negara Indonesia yang menyalurkan kredit kepada PT Dipasena

${ }^{1}$ J. Didik J. Rachbini (ed), Bank Indonesia Menuju Independensi Bank Sentral, PT Mardi Mulyo, Jakarta, 2000, hlm. 11 Dikutip dari Ridwan Khairandy, Hukum Perseroan Terbatas, Cetakan Pertama, FH UII Press, Yogyakarta, 2014, hlm. 364

${ }^{2}$ Ibid, hlm. 381

3 Bank Indonesia menyalurkan BLBI kepada Bank Modern sebesar Rp. 2.500.000.000.000.000,00, kemudian Hartono sebagai pemegang saham mayoritas bank tersebut telah melakukan penyimpangan pemanfataan BLBI berupa transaksi valuta asing dan penarikan dana untuk kelompok perusahaan terkait atau terafiliasi untuk peningkatan aktivitas produksi mencapai Rp. 766.000.000.000,00. 
yang masih berada dalam satu kelompok perusahaan, namun pemerintah dinilai mengesampingkan penyelesaian melalui instrumen pidana kepada pemegang saham pengendali (PSP). ${ }^{4}$

Penyelesaian Kewajiban Pemegang Saham (PKPS) sebagai bentuk tanggung jawab pribadi pemegang saham antara lain dilakukan dengan instrumen Master of Settlement and Acquisition Agreement (MSAA) dan Master Refinancing and Note Issuance Agreement (MRNIA). MSAA dan MRNIA dibuat untuk mempercepat penyelesaian utang BLBI, bagi bank-bank penerima utang BLBI yang mempunyai iktikad baik untuk menandatangani PKPS baik berupa MSAA atau MRNIA, maka bagi yang bersangkutan diberikan jaminan dengan klausula release and discharge (pembebasan dan pengosongan) yang merupakan bentuk pembebasan penuntutan aspek pidananya. Dibuatlah perjanjian yang di dalamnya memuat klausula release and discharge antara BPPN dan debitor penerima utang BLBI. Klausula Release and Discharge dalam perjanjian MSAA dan MRNIA menegaskan bahwa bagi debitor yang telah menyelesaikan kewajiban pemegang saham, diberikan bukti penyelesaian berupa pelepasan dan pembebasan dalam rangka jaminan kepastian hukum atau lebih dikenal dengan surat keterangan lunas. Ketentuan release and discharge menyatakan bahwa tidak akan menuntut secara pidana terhadap PSP bank dan pengurus serta karyawan bank apabila telah diterima pembayaran atau pelunasan dari PSP bank baik yang berupa kredit melanggar BMPK bagi bank berstatus Bank Take Over (BTO) dan melanggar BMPK dan BLBI yang berstatus Bank Beku Operasi (BBO) atau Bank Beku Kegiatan Usaha (BBKU).

Adanya pembebasan aspek pidana tersebut, menyebabkan negara khususnya rakyat harus menanggung utang yang dilakukan oleh bank penerima utang BLBI, sedangkan para PSP bank yang melakukan pelanggaran BMPK tidak menanggung sanksi yang seharusnya akibat dari perbuatannya. Padahal menurut Pasal 1853 Kitab Undang-undang Hukum Perdata (KUHPer), klausula release and discharge bukan merupakan pembebasan dari unsur pidana namun merupakan suatu

${ }^{4}$ Ridwan Khairandy, Op. Cit., hlm. 384 


\section{IEx Renaissance No. 1 VOL. 3 JANUARI 2018: 1 - 24}

penundaan penuntutan selama proses penyelesaian dan sarana mengurangi hukuman seandainya dapat menyelesaikan kewajibannya.

Klausula release and discharge yang terdapat di dalam MSAA dan MRNIA ternyata di kemudian hari menimbulkan persoalan hukum baik menyangkut kekuatan hukum maupun akibat hukumnya. Di kemudian hari diketahui terjadi penyalahgunaan utang BLBI yang semula dimaksudkan untuk dibayarkan kepada nasabah beralih kepada penggunaan dana tersebut untuk kepentingan pribadi pemilik bank-bank penerima utang BLBI. Permasalahan kemudian berlanjut pada penyelesaian utang BLBI yang disebabkan karena tidak sesuainya aset yang dijaminkan atau kaburnya pemilik bank-bank penerima utang BLBI.

\section{Rumusan Masalah}

Berdasarkan uraian yang telah dipaparkan pada latar belakang masalah di atas, maka disusun rumusan masalah sebagai berikut: Pertama, bagaimana kekuatan hukum release and discharge dalam MSAA dan MRNIA? Kedua, bagaimana akibat hukum release and discharge dalam MSAA dan MRNIA terhadap tanggung jawab pribadi pemegang saham utang BLBI?

\section{Tujuan Penelitian}

Tujuan penelitian ini adalah: Pertama, untuk mengkaji dan mengetahui kekuatan hukum release and discharge dalam MSAA dan MRNIA. Kedua, untuk mengkaji dan mengetahui akibat hukum release and discharge dalam MSAA dan MRNIA terhadap tanggung jawab pribadi pemegang saham utang BLBI.

\section{Metode Penelitian}

Penelitian ini termasuk jenis penelitian kualitatif dengan mengikuti tipologi penelitian hukum normatif. Pendekatan yang digunakan dalam penelitian ini adalah pendekatan konseptual, yaitu dengan cara mengkaji konsep perjanjian MSAA dan MRNIA yang di dalamnya terdapat klausula release and discharge. Penelitian ini menggunakan bahan hukum primer, yakni Kitab Undang-Undang Hukum Perdata, UU No. 10 Tahun 1998 tentang Perbankan, dan UU No. 40 Tahun 2007 tentang Perseroan Terbatas. Selain itu, penelitian ini menggunakan bahan 
hukum sekunder yakni buku, jurnal, hasil penelitian yang mendukung bahan hukum sekunder, serta bahan hukum tersier yaitu kamus hukum seperti Black's Law Dictionary. Data penelitian dikumpulkan dengan cara studi pustaka dan dokumen. Kemudian seluruh data yang diperoleh dari studi kepustakaan dan studi dokumen tersebut direlevansikan dengan teori Piercing the Corporate Veil serta dituliskan secara deskriptif dan dianalisa secara kualitatif.

\section{Hasil Penelitian dan Pembahasan}

\section{Kekuatan Hukum Release and Discharge dalam MSAA dan MRNIA}

Upaya hukum penyelesaian utang BLBI kepada negara dengan cara non litigasi yang dilakukan pemerintah dengan menggunakan perjanjian, menunjukkan bahwa pemerintah telah mengakui tagihan BLBI adalah milik negara, dengan cara menerbitkan Surat Utang Negara kepada BI, sehingga terjadi cessie atau pengalihan hak penagihan, oleh karenanya dalam Neraca Bank Indonesia, BLBI telah lunas, dan sebagai konsekuensi yuridisnya adalah hak tagih BLBI beralih kepada pemerintah. ${ }^{5}$

Pengembalian uang negara yang disalurkan kepada Bank Dalam Pengawasan (BDP), BLBI, dana talangan, dan program penjaminan, pemerintah membentuk BPPN yang bertugas: ${ }^{6}$

1. Menyehatkan bank yang ditetapkan dan diserahkan BI;

2. Menyelesaikan aset bank, aset fisik maupun kewajiban debitor melalui Asset Management Unit (AMU);

3. Mengupayakan uang negara yang telah disalurkan melalui penyelesaian aset dalam restrukturisasi;

4. Menjual aset dan melaporkannya kepada Menteri Keuangan;

5. Melakukan penyertaan modal sementara dan pengalihan modal;

6. Mengosongkan tanah atau bangunan yang menjadi hak milik bank dalam penyehatan;

7. Mengambil alih dan menjual aset dalam restrukturisasi melalui penawaran umum melalui lelang;

8. Menagih kepada debitor dengan menerbitkan surat paksa;

9. Menyita kekayaan debitor;

\footnotetext{
${ }^{5}$ Zulfi Diane Zaini, Independensi Bank Indonesia dan Penyelesaian Bank Bermasalah, Cetakan Pertama, Bandung, Keni Media, 2012, hlm. 210

${ }^{6}$ Humas BI, "Menatap Masa Depan, Menata Masa Lalu”, Kompas, 27 Desember 2001, Dikutip dari Ridwan Khairandy, Huk.um Perseroan Terbatas, Op. Cit., hlm. 387
} 
Kewenangan tersebut menjadi sarana BPPN menyelesaikan utang BLBI dengan PSP bank melalui perjanjian novasi (pembaharuan utang) dalam bentuk MSAA dan MRNIA. Pasal 1413 angka 1 dan 2 serta Pasal 1381 KUHPerdata menyatakan bahwa utang lama akan hapus apabila seseorang ditunjuk untuk menggantikan debitor lama.7 Kata "menggantikan" mengandung arti bahwa perikatan yang lama sengaja dihapuskan dan sebagai gantinya dibuatkan perjanjian baru, yang melahirkan perikatan sebagai ganti yang lama. “Segaja dihapuskan" berarti bahwa para pihak memang menghendakinya atau dengan perkataan lain didasarkan bahwa novasi selalu diperjanjikan. Karena novasi harus diperjanjikan, maka perjanjian novasi harus memenuhi semua syarat-syarat untuk sahnya perjanjian. ${ }^{8}$

MSAA merupakan suatu perjanjian penyelesaian kewajiban lewat penyerahan aset. Penyerahan itu berlangsung melalui akuisisi aset oleh BPPN atau lewat pihak yang ditunjuknya. MSAA diberlakukan terhadap PSP bank yang masih memiliki harta cukup untuk menyelesaikan kewajibannya terhadap pemerintah. Ada dua jenis MSAA, yaitu MSAA terhadap PSP bank berstatus BBO atau BBKU dan MSAA terhadap PSP Bank berstatus BTO. ${ }^{9}$

Kewajiban yang harus dibayar PSP Bank yang berstatus BBO dan BBKU adalah sebesar kewajiban BLBI terutang, dikurangi dengan nilai clean aset bank. Kewajiban yang harus dibayar oleh PSP Bank yang berstatus BTO dan direkapitalisasi adalah sebesar jumlah kewajiban kredit yang melanggar BMPK kepada pihak terkait. Sesuai dengan MSAA, pembayaran kewajiban bank dilakukan oleh PSP Bank secara tunai dan in kind, yaitu dengan menyerahkan aset. Pembayaran dengan aset ini dilakukan melalui transfer agreement, yaitu bank-bank

\footnotetext{
${ }^{7}$ Pasal 1413 angka 1 KUHPerdata: "Apabila seorang yang berpiutang membuat suatu perikatan utang baru guna orang yang mengutangkan kepadanya, yang menggantikan utang yang lama, yang dihapuskan karenanya." Pasal 1413 angka 2 KUHPerdata: "Apabila seorang berutang baru ditunjuk untuk menggantikan orang berutang lama, yang oleh si berpiutang dibebaskan dari perikatannya." Pasal 1381 KUHPerdata: Perikatan-perikatan hapus: karena pembayaran; karena penawaran pembayaran tunai, diikuti dengan penyimpanan atau penitipan; karena pembaharuan utang; karena perjumpaan utang atau kompensasi; karena percampuran utang; karena pembebasan utangnya; karena musnahnya barang yang terutang; karena kebatalan atau pembatalan; karena berlakunya suatu syarat batal, yang diatur dalam bab ke satu buku ini; karena liwatnya waktu, hal mana akan diatur dalam suatu bab tersendiri.

${ }^{8}$ J. Satrio, Cessie, Subrogatie, Novatie, Kompensatie \& Percampuran Utang, Cetakan Kedua, Alumni, Bandung, 1999, hlm. 101

9 Satgas BLBI Bank Indonesia, Studi Kenangan Bantuan Likuiditas Bank Indonesia, Cetakan Pertama, Bank Indonesia, Jakarta, 2002, hlm. 99
} 
menyerahkan saham-saham dari perusahaan yang dimiliki dengan nilai yang disepakati sebelumnya. Saham-saham tersebut diserahkan kepada perusahaan yang dibentuk untuk itu (holding company yang juga disebut aqusition vehicle-AV).10

MRNIA merupakan suatu penyelesaian kewajiban antara PSP Bank dengan BPPN, dengan cara penyerahan aset, yang berlaku bagi PSP Bank yang asetnya tidak mencukupi untuk membayar kewajibannya terhadap pemerintah, dan karena sebagaian utangnya telah dibayar tunai, maka untuk pelunasan sisa utangnya, PSP Bank menyerahkan daftar aset yang dimasukkan dalam jaminan pribadi (personal guarantee) untuk melunasi utangnya sesuai dengan batas waktu yang ditetapkan. ${ }^{11}$ MRNIA ditempuh apabila PSP Bank menyepakati Jumlah Kewajiban Pemegang Saham (JKPS), namun tidak menyepakati nilai aset yang dijaminkan maka PSP Bank menyerahkan PG sebesar JKPS. Untuk mengelola aset yang dijaminkan atau diserahkan dibentuk perusahaan holding company yang sahamnya dimiliki oleh PSP Bank yang bersangkutan namun pemerintah mempunyai hak-hak sebagai pemegang saham atas holding company tersebut sampai seluruh JKPS dilunasi. Holding company menyerahkan promissory notes sebesar JKPS setelah dikurangi setoran tunai dan deposito kepada BPPN. Pelunasan promissory notes dilakukan dari hasil penjualan aset atas holding company. Apabila nilai aset yang dijual lebih rendah dari nilai JKPS, maka kekurangannya ditanggung oleh PSP Bank yang bersangkutan. ${ }^{12}$

Secara umum dapat dikatakan bahwa MSAA dan MRNIA adalah pola penyelesaian utang BLBI yang hampir sama. Perbedaanya terletak pada nilai aset, pola MSAA dipilih jika PSP Bank memiliki cukup aset untuk membayar utang BLBI, sedangkan MRNIA dipilih jika PSP Bank tidak memiliki aset yang cukup

\footnotetext{
${ }^{10}$ Ridwan Khairandy, Hukum Perseroan Terbatas, Op. Cit., hlm. 389

11 Kusumaningtuti SS, Peranan Hukum dalam Penyelesaian Krisis Perbankan di Indonesia, Cetakan Pertama, Rajawali Pers, Jakarta, 2009, hlm. 182

${ }^{12}$ Satgas BLBI Bank Indonesia..., Op. Cit., hlm. 98
} 
untuk melunasi utangnya. ${ }^{13}$ Ada beberapa perbedaan antara MSAA dan MRNIA dalam program PKPS dengan parameter sebagai berikut:14

1. Nilai aset MSAA cukup untuk membayar total utang, sedangkan nilai aset MRNIA tidak mencukupi.

2. Pada MSAA hold back aset disiapkan untuk menutupi kekurangan aset, pada MRNIA yang menanggung kekurangan nilai aset adalah pemegang saham.

3. Pada MSAA tidak ada personal guarantee, sedangkan pada MRNIA dibutuhkan adanya personal guarantee.

4. Pada MSAA ada management company dan management contract, sebaliknya pada MRNIA keduanya tidak ada.

5. Pada MSAA asset disposal atas pertimbangan BPPN, sedangkan pada MRNIA asset disposal ditentukan oleh pemegang saham.

6. Resiko pasar dan komersial pada MSAA ditanggung oleh BPPN, sedangkan pada MRNIA ditanggung oleh pemegang saham.

Perjanjian MSAA dan MRNIA mengandung klausula release and discharge yang akan diberikan kepada pemegang saham yang telah melakukan pembayaran utang BLBI. Secara harfiah, istilah release and discharge menurut Black Law Dictionary memberikan pengertian release sebagai liberation from an obligation, or duty, yang diterjemahkan sebagai kebebasan dari suatu kewajiban (tanggung jawab) atau suatu tugas. Sedangkan discharge diartikan sebagai the payment of debt or satisfaction of some other obligation; or the release of a debtor from monetary obligations upon adjudication of bankruptcy, yang diterjemahkan sebagai pembayaran dari suatu utang atau kewajiban untuk membayar dari beberapa kewajiban lainnya; atau pembebasan seorang debitor dari kewajiban moneter berdasarkan keputusan hakim yang menyatakan kebangkrutan. ${ }^{15}$

Istilah release and discharge ( $R$ \& $D$ ) sebenarnya tidak dikenal dalam pranata hukum Indonesia. Menurut Jusuf L. Indradewa, di Indonesia yang dikenal dan biasa digunakan adalah pemberian acqint et decharge (A \& D) dalam rangka pelepasan dan pembebasan tanggung jawab direksi dan dewan komisaris

13 Ari Wahyudi Hertanto, "Master Settlement and acquisition Agreement (MSAA) dan Master Refinancing and Note Issuance Agreement (MRNIA) dalam Perspektif Hukum Perdata (Suatu Tinjauan Singkat)", Jurnal Hukum dan Pembangunan, Edisi No. 4 Vol. 35 (2005), hlm. 440

14 Tim Humanika (Ed), BLBI: Megaskandal Ekonomi Indonesia, Cetakan Pertama, Humanika, Jakarta, 2001, hlm. 49

15 Sie Infokum-Ditama Binbangkum, terdapat dalam https://www.jdih.bpk.go.id/ informasihukum/ReleasedDischarge.pdf Dikutip dari Tesis Lily Evelina Sitorus, Release and Discharge Sebagai Alternatif Penyelesaian Masalab (Studi Kasus Kebijakan Penyelesaian BLBI), Fakultas Ilmu Sosial dan Ilmu Politik Universitas Indonesia, Depok, 2009, hlm. 17-18, diakses pada tanggal 30 Januari 2017 
perseroan terbatas yang selalu diikuti penegasan, bila kemudian ternyata telah terjadi tindak pidana selama masa jabatannya, maka akan dilakukan penuntutan sesuai dengan ketentuan undang-undang hukum pidana. ${ }^{16}$

Release and discharge termuat dalam perjanjian antara BPPN dengan para PSP bank berdasarkan PKPS, baik yang berbentuk MSAA atau MRNIA. Tujuan dari pemberian release and discharge adalah penyelesaian utang BLBI dan pelanggaran BMPK dengan pembebasan dari semua tuntutan hukum, termasuk aspek pidananya. Penyelesaian utang BLBI yang dipilih pemerintah melalui BPPN dengan cara MSAA atau MRNIA dinilai lebih efektif dengan tujuan pengembalian utang BLBI yang lebih diutamakan.

Penerbitan release and discharge dikuatkan melalui Instruksi Presiden Nomor 8 Tahun 2002 tentang Pemberian Jaminan Kepastian Hukum Kepada Debitur yang Telah Menyelesaikan Kewajibannya atau Tindakan Hukum Kepada Debitur yang Tidak Menyelesaikan Kewajibannya Berdasarkan Penyelesaian Kewajiban Pemegang Saham (release and discharge). Alasan diterbitkannya Instruksi Presiden tersebut sesuai dengan Ketetapan MPR Nomor X/MPR/2001 yang memerintahkan untuk konsisten terhadap kesepakatan penyelesaian utang para debitor melalui mekanisme MSAA atau perjanjian penyelesaian BLBI dengan jaminan aset. Selain itu, Undang-Undang Nomor 25 Tahun 2000 tentang Program Pembangunan Nasional menuntut pemerintah memberikan insentif kepada para obligor yang kooperatif. ${ }^{17}$

Klausula release and discharge dalam perjanjian MSAA dan MRNIA menegaskan bahwa bagi debitor yang telah menyelesaikan kewajiban pemegang saham, diberikan bukti penyelesaian berupa pelepasan dan pembebasan dalam rangka jaminan kepastian hukum atau lebih dikenal dengan surat keterangan lunas. Ketentuan release and discharge menyatakan bahwa tidak akan menuntut secara pidana terhadap PSP bank dan pengurus serta karyawan bank apabila telah diterima pembayaran atau pelunasan dari PSP bank baik yang berupa kredit

\footnotetext{
${ }^{16}$ Erna Herlinda, Release and Discharge dalam Perspektif Hukum Kenangan Publik, e-USU Repository, 2004, hlm. 3 terdapat dalam http://library.usu.ac.id/download/fh/fh-erna3.pdf, diakses pada tanggal 3 Februari 2017

17 Zulfi Diane Zaini, Op. Cit., hlm. 208
} 


\section{Lx Renaissance No. 1 VOL. 3 JANUARI 2018: 1 - 24}

melanggar BMPK bagi bank berstatus Bank Take Over (BTO) dan melanggar BMPK dan BLBI yang berstatus Bank Beku Operasi (BBO) atau Bank Beku Kegiatan Usaha (BBKU). ${ }^{18}$ Namun kenyataannya, klausula release and discharge dalam perjanjian MSAA dan MRNIA yang menyatakan jika hasil penjualan aset melebihi utang, kelebihan itu menjadi hak debitor, namun jika ternyata hasil penjualan aset tidak mencukupi untuk membayar utang, kekurangannya menjadi tanggung jawab BPPN dan dibebankan kepada pemerintah melalui APBN.

Para pihak, dalam hal ini BPPN dan PSP bank, diberikan kebebasan dalam merumuskan MSAA dan MRNIA sebagai bentuk perjanjian. Namun, kebebasan tersebut dibatasi dengan iktikad baik para pihak yang diatur dalam Pasal 1338 KUHPerdata. ${ }^{19}$ Iktikad baik dalam perjanjian dibedakan antara iktikad baik prakontrak (precontractual good faith) dan iktikad baik pelaksanaan kontrak (good faith on contract performance). Iktikad baik prakontrak adalah iktikad yang harus ada pada saat para pihak melakukan negosiasi. Iktikad baik prakontrak ini bermakna kejujuran (honesty). Iktikad baik ini disebut iktikad baik yang bersifat subjektif, karena didasarkan pada kejujuran para pihak yang melakukan negosiasi. Sedangkan iktikad baik pelaksanaan kontrak yang disebut sebagai iktikad baik objektif mengacu kepada isi perjanjian. Isi perjanjian harus rasional dan patut. Isi kontrak adalah kewajiban dan hak para pihak yang mengadakan kontrak. Kewajiban dan hak tersebut harus rasional dan patut. Iktikad baik pelaksanaan kontrak juga dapat bermakna melaksanakan secara rasional dan patut. ${ }^{20}$

BPPN dan PSP bank harus memiliki iktikad baik dalam masa prakontrak dan pelaksanaan kontrak. Adanya klausula release and discharge dalam perjanjian MSAA dan MRNIA yang menyatakan jika hasil penjualan aset melebihi utang, kelebihan itu menjadi hak debitor, namun jika ternyata hasil penjualan aset tidak mencukupi untuk membayar utang, kekurangannya menjadi tanggung jawab BPPN dan dibebankan kepada pemerintah melalui APBN, mengindikasikan tidak adanya

${ }^{18}$ Kusumaningtuti SS, Op. Cit., hlm. 182

19 Pasal 1338 KUHPerdata: "Semua perjanjian yang dibuat secara sah berlaku sebagai undang-undang bagi mereka yang membuatnya". "Suatu perjanjian tidak dapat ditarik kembali selain dengan sepakat kedua belah pihak, atau karena alasan-alasan yang oleh undang-undang dinyatakan cukup untuk itu". "Suatu perjanjian harus dilaksanakan dengan iktikad baik".

${ }^{20}$ Ridwan Khairandy, Kebebasan Berkontrak \& Pacta Sunt Servanda versus Iktikad Baik: Sikapyang Harus Diambil Pengadilan, Cetakan Pertama, FH UII Press, Yogyakarta, 2015, hlm. 16 
iktikad baik pra kontrak dari PSP bank. Perumusan klausula release and discharge mengindikasikan bahwa PSP bank dengan sengaja ingin mengambil keuntungan dengan mengalihkan kekurangan pelunasan utang BLBI kepada BPPN. Selain itu, PSP bank dinilai telah mengalihkan tanggung jawabnya kepada BPPN jika memang dikemudian hari terdapat kekurangan atas pembayaran utang BLBI.

Iktikad baik dalam implementasi perjanjian MSAA dan MRNIA juga harus tercermin dalam pelaksaan perjanjian. Dalam hal penyerahan asset, PSP bank tidak menyerahkan aset yang cukup tetapi release and discharge terlanjur diberikan, sehingga kekurangan pembayaran utang BLBI menjadi tanggung jawab BPPN. Tindakan yang dilakukan oleh PSP bank dengan cara menyerahkan aset yang ternyata tidak cukup untuk melunasi utang BLBI menunjukkan bahwa PSP bank tidak melaksanakan iktikad baik dalam pelaksanaan perjanjian.

Perjanjian MSAA dan MRNIA dengan klausula release and discharge juga harus memenuhi syarat sah perjanjian seperti yang terdapat dalam Pasal 1320 KUHPerdata yaitu, kata sepakat, kecakapan, suatu hal tertentu, dan kausa yang halal. Sepanjang syarat sah suatu perjanjian dapat dipenuhi, maka perjanjian tersebut dinilai sah. Namun, apabila syarat sah perjanjian tidak terpenuhi maka perjanjian tersebut menjadi batal demi hukum atau dapat dibatalkan. ${ }^{21}$ Supaya perjanjian menjadi sah, maka para pihak harus sepakat terhadap segala hal yang terdapat di dalam perjanjian. ${ }^{22}$ Pada dasarnya kata sepakat adalah pertemuan atau persesuaian kehendak antara para pihak di dalam perjanjian. Seseorang dikatakan memberikan persetujuannya atau kesepakatannya jika ia memang menghendaki apa yang disepakati. ${ }^{23}$ Di dalam pembentukan kata sepakat (toesteming) terdapat unsur penawaran (offer, offerte) dan penerimaan (acceptance, acceptatie). Kata sepakat pada prinsipnya adalah terjadinya persesuaian antara penawaran dan penerimaan. Kata sepakat itu sendiri pada dasarnya adalah pertemuan antara dua kehendak. ${ }^{24}$

${ }^{21}$ Ridwan Khairandy, Hukum Kontrak Indonesia dalam Perspektif Perbandingan (Bagian Pertama), Cetakan Kedua, FH UII Press, Yogyakarta, 2014, hlm. 192

22 Sudargo Gautama, Indonesia Business Law, Cetakan Pertama, Citra Aditya Bakti, Bandung, 1995, hlm. 76 Dikutip dari Ridwan Khairandy..., Ibid, hlm. 168

${ }^{23}$ J. Satrio, Hukum Perikatan..., Op. Cit., hlm. 164 168-169

${ }^{24}$ Ridwan Khairandy, Hukum Kontrak Indonesia dalam Perspektif Perbandingan (Bagian Pertama), Op. Cit., hlm. 


\section{Lx Renaissance No. 1 VOL. 3 JANUARI 2018: 1 - 24}

Kesepakatan yang dicapai oleh BPPN dan PSP Bank bukan merupakan pertemuan penawaran dan penerimaan antara kedua belah pihak. Awal mula perjanjian MSAA dan MRNIA merupakan usulan dari pemerintah melalui BPPN untuk menyelesaiakan utang BLBI dengan tujuan untuk pengembalian utang. Sehingga PSP Bank harus menerima perjanjian tersebut untuk menyelesaikan kewajibannya sebagai bentuk tanggung jawab pribadi pemegang saham perseroan seperti diatur dalam Pasal 3 ayat (2) UUPT. PSP Bank yang terbukti menyalahgunakan peruntukan BLBI tetapi mempunyai iktikad baik menyelesaikan utang BLBI diberikan wadah berupa MSAA dan MRNIA sebagai bentuk tanggung jawab. Kemudian dibuatlah perjanjian bagi PSP Bank baik yang berupa MSAA atau MRNIA antara BPPN dan debitor penerima utang BLBI sebagai realisasi Inpres release and discharge.

Klausula release and discharge yang menyatakan bahwa jika hasil penjualan aset melebihi utang, kelebihan itu menjadi hak debitor, namun jika ternyata hasil penjualan aset tidak mencukupi untuk membayar utang, kekurangannya menjadi tanggung jawab BPPN dan dibebankan kepada pemerintah melalui APBN, merupakan bentuk pemaksaan. BPPN terpaksa menanggung kerugian akibat tidak dipenuhinya pelunasan utang BLBI. Hal ini menunjukkan bahwa kata sepakat dalam perjanjian MSAA dan MRNIA hanya tercapai secara formal. Secara material kata sepakat tidak tercapai melalui pernyataan kehendak dalam wujud tandatangan kedua belah pihak, yaitu BPPN dan PSP Bank. Hal itu dikarenakan kesepakatan yang dicapai oleh kedua belah pihak dilandasi unsur terpaksa demi tercapainya penyelesaian utang BLBI.

Klausula release and discharge dalam perjanjian MSAA dan MRNIA yang menegaskan bahwa bagi debitor yang telah menyelesaikan kewajiban pemegang saham, diberikan bukti penyelesaian berupa pelepasan dan pembebasan dalam rangka jaminan kepastian hukum atau lebih dikenal dengan surat keterangan lunas. Sehingga bagi PSP Bank yang telah menempuh jalur MSAA dan MRNIA yang di dalamnya terdapat klausula release and discharge maka tidak akan dimintakan pertanggungjawaban pelunasan utang BLBI serta dibebaskan dari aspek pidana. Kenyataannya, PSP Bank yang menempuh jalur MSAA menyerahkan aset yang dari awal tidak cukup untuk melunasi utangnya namun release and discharge sudah diberikan terlebih dahulu tanpa menghitung nilai aset 
yang diserahkan tersebut, seperti dalam kasus BCA dan RSI, Sudono Salim, Anthoni Salim, Andree Salim selaku pemegang saham pengendali mentransfer aset ke PT Holdiko sebagai aquisitor company yang memberikan kuasa yang dimaksud kepada BPPN, maka tugas BPPN adalah menjual aset-aset tersebut. Ketentuan ini disertai klausul bahwa jika hasil penjualan aset melebihi utang, kelebihan itu menjadi hak PT Holdiko, namun jika ternyata hasil penjualan aset tidak mencukupi untuk membayar utang, kekurangannya menjadi tanggung jawab BPPN. Dengan demikian kerugian tersebut menjadi beban negara. ${ }^{25}$

Pasal 1340 KUHPerdata menyatakan bahwa: "suatu perjanjian hanya berlaku antara pihak-pihak yang membuatnya". "Suatu perjanjian tidak dapat membawa rugi kepada pihak-pihak ketiga, tak dapat pihak-pihak ketiga mendapat manfaat karenanya". Berdasarkan hal tersebut, maka rakyat sebagai pihak ketiga seharusnya tidak menanggung utang BLBI yang dibebankan kepada pemerintah melalui APBN. Sehingga adanya klausula release and discharge mengakibatkan salah satu syarat perjanjian yaitu suatu kausa yang halal tidak terpenuhi yang dibuktikan dengan Pasal 1337 KUHPerdata menyatakan bahwa "suatu sebab adalah terlarang, apabila dilarang oleh undang-undang, atau apabila berlawanan dengan kesusilaan baik atau ketertiban umum".

Berdasarkan hal tersebut, maka secara formal, perjanjian MSAA dan MRNIA telah memenuhi syarat sah perjanjian yaitu adanya kata sepakat, kecakapan, suatu hal tertentu, dan kausa yang halal. Namun secara material, klausula release and discharge dalam perjanjian MSAA dan MRNIA dapat membatalkan syarat sahnya perjanjian yaitu kata sepakat dan kausa yang halal. Jika demikian, maka release and discharge tidak memiliki kekuatan hukum karena syarat sah perjanjian tidak terpenuhi. Syarat sah perjanjian yang tidak terpenuhi yaitu kata sepakat yang merupakan salah satu syarat subjektif sehingga berakibat perjanjian dapat dibatalkan. Sedangkan tidak terpenuhinya kausa yang halal yang merupakan syarat objektif mengakibatkan perjanjian batal demi hukum. Meskipun syarat dapat dibatalkannya perjanjian harus berdasarkan putusan pengadilan, namun

${ }^{25}$ Ridwan Khairandy, Hukum Perseroan Terbatas, Op. Cit., hlm. 396 


\section{Lx Renaissance No. 1 VOL. 3 JANUARI 2018: 1 - 24}

karena perjanjian juga sudah batal demi hukum maka hal ini berarti perjanjian sejak pertama kali dibuat telah tidak sah, sehingga hukum menganggap bahwa perjanjian tersebut tidak pernah ada sebelumnya.

\section{Akibat Hukum Release and Discharge dalam MSAA dan MRNIA Terhadap Tanggung Jawab Pribadi Pemegang Saham Utang BLBI}

Perjanjian PKPS baik berupa MSAA atau MRNIA yang mengandung klausula release $\mathcal{E}$ discharge memberikan akibat hukum bahwa PSP Bank, pengurus, serta karyawan tidak akan dituntut secara pidana apabila telah diterima pembayaran atau pelunasan dari PSP Bank baik yang berupa kredit melanggar BMPK bagi bank berstatus BTO dan melanggar BMPK dan BLBI yang berstatus BBO atau BBKU. Namun dalam kenyataannya PSP Bank tidak memberikan pembayaran penuh terhadap seluruh utangnya, tetapi sudah diberikan release and discharge. Hal tersebut mengakibatkan PSP Bank tidak dapat dimintakan pertanggungjawaban apapun dengan diberikannya release and discharge.

Secara formal, perjanjian MSAA dan MRNIA dengan klausula release and discharge mempunyai akibat hukum bagi PSP Bank, pengurus, serta karyawan tidak akan dituntut secara pidana setelah diterima pembayaran utang BLBI. Khususnya bagi PSP Bank yang bertanggung jawab secara pribadi terhadap utang BLBI tersebut, tidak akan dituntut secara pidana. Kekuatan hukum tersebut juga diperoleh karena perjanjian MSAA dan MRNIA memenuhi unsur syarat sah perjanjian. Namun secara material, klausula release and discharge di dalam MSAA dan MRNIA tidak memiliki kekuatan hukum karena sejak awal perjanjian tidak memenuhi syarat subjektif dan syarat objektif perjanjian yaitu kata sepakat dan kausa yang halal, sehingga berakibat perjanjian dapat dibatalkan dan batal demi hukum.

Suatu perjanjian yang telah batal demi hukum berarti perjanjian sejak pertama kali dibuat telah tidak sah, sehingga hukum menganggap bahwa perjanjian tersebut tidak pernah ada sebelumnya. Jika dari awal perjanjian tersebut tidak pernah ada, maka akibat hukum yang seharusnya dibebankan terhadap para pihak juga tidak pernah terjadi. Khususnya bagi PSP Bank, atas adanya klausula release and discharge di dalam MSAA dan MRNIA maka baginya dibebaskan dari pengembalian utang BLBI dan penuntutan aspek pidananya, namun jika perjanjian yang berbentuk MSAA atau MRNIA batal demi hukum, maka akibat hukum yang 
seharunya ada juga tidak berlaku bagi PSP Bank. Dengan demikian, maka PSP bank dapat dimintakan pertanggungjawaban secara pribadi terhadap utang BLBI.

Tanggung jawab pribadi pemegang saham dalam utang BLBI dapat dimintakan sampai kepada harta pribadi dengan berlandaskan pada Pasal 3 ayat (2) UUPT. PSP Bank tidak dapat berlindung dibalik klausula release and discharge dalam perjanjian MSAA atau MRNIA karena telah batal demi hukum. Dengan demikian, maka PSP Bank dapat dimintakan pertanggungjawaban sampai kepada harta pribadi terhadap utang BLBI yang ternyata belum dilakukan pelunasan secara penuh. PSP Bank tidak dapat berlindung dibalik klausula release and discharge di dalam MSAA dan MRNIA karena secara material perjanjian tersebut telah batal demi hukum dan tidak memiliki kekuatan hukum.

Klausula release and discharge juga mengindikasikan adanya deponering atau pengesampingan perkara. Dasar penyampingan perkara ini, karena hukum acara menganut asas oportunitas. Dimana suatu perkara (perbuatan pidana) jika dilimpahkan ke persidangan diperkirakan akan menimbulkan suatu goncangan di kalangan masyarakat atau dengan penyidangan perkara tersebut akan menimbulkan akibat negatif di kalangan masyarakat luas. ${ }^{26}$ Keberadaan asas oportunitas tersebut adalah untuk melihat apakah suatu perkata tersebut layak dilakukan penuntutan atau tidak dengan melihat bukan saja dari sudut pandang sebab akibatnya perkara melainkan dari sudut pandang kepentingan umum. Seperti yang dikatakan dalam pedoman pelaksana Kitab Undang-Undang Hukum Acara Pidana (KUHAP) yang memberi penjelasan "dengan demikian, kriteria demi kepentingan umum dalam penerapan asas oportunitas di negara kita adalah didasarkan untuk kepentingan negara dan masyarakat dan bukan untuk kepentingan masyarakat."27

Asas oportunitas dilaksanakan dalam posisi ini Jaksa Agung berpedoman pada ketentuan Pasal 35 huruf c UU Nomor 16 Tahun 2004 tentang Kejaksaan Republik Indonesia yang mengatakan Jaksa Agung memiliki wewenang untuk

26 Osman Simanjuntak, Tehnik Penuntutan dan Upaya Hukum, Cetakan Pertama, Gramedia Widiasarana Indonesia, Jakarta, 1995, hlm. 90, Dikutip dari Jony Hinaibaho, Penyampingan Perkara Pidana (Deponering) Berdasarkan Asas Oportunitas Oleh Jaksa Agung RI, Skripsi, Fakultas Hukum Universitas Sumatera Utara, Medan, 2010, hlm. 17

${ }_{27}$ Bryan Saputra Tambuwun, 'Upaya Hukum Terhadap Deponering dalam Perspektif Hukum Progresif”, Jurnal Lex Crimen, Edisi No. 2 Vol IV, (2015), hlm. 192 
menyampingkan perkara demi kepentingan umum, dalam penjelasan Pasal 35 huruf c dikatakan bahwa kepentingan umum yang dimaksudkan adalah kepentingan bangsa dan negara dan/atau masyarakat luas dengan meminta saran dan pendapat dari badan kekuasaan negara yang memiliki hubungan dengan masalah tersebut. ${ }^{28}$ Apabila hal ini dikaitkan dengan hukum pidana materiil, maka penyampingan perkara terdiri dari dua golongan yaitu: Penyampingan perkara berdasarkan asas oportunitas; atau penyampingan perkara atas dasar penilaian hukum pidana (strafrechtelijk). ${ }^{29}$

Adanya deponering dalam kasus BLBI melalui klausula Release and Discharge dalam MSAA dan MRNIA bukan merupakan suatu hal yang tepat untuk dilakukan. Mengingat dengan adanya deponering, negara khususnya rakyat harus menanggung utang yang dilakukan oleh bank penerima utang BLBI yang dibebankan melalui APBN, sedangkan para PSP Bank yang melakukan pelanggaran BMPK tidak menanggung sanksi yang seharusnya didapatkan akibat dari perbuatannya. Tujuan dari adanya deponering yang semula untuk menghindari dampak negatif di kalangan masyarakat luas justeru tidak tercapai. Hal itu karena dengan adanya deponering masyarakat justeru harus menanggung dampak yang lebih berat lagi baik dari segi tidak dapat diterapkannya sanksi PSP Bank pelanggar BMPK maupun dari segi kerugian secara material yaitu menanggung utang yang dilakukan oleh orang lain dengan dibebankan dalam APBN.

Bank dalam melakukan kegiatan usaha terutama dengan menggunakan dana masyarakat yang dipercayakan kepada bank. Pemberian kredit merupakan kegiatan utama bank yang mengandung risiko yang dapat berpengaruh pada kesehatan dan kelangsungan usaha bank, sehingga dalam pelaksanaannya bank harus berpegang pada azas-azas perkreditan yang sehat guna melindungi dan memelihara kepentingan dan kepercayaan masyarakat. ${ }^{30}$ Agar pemberian kredit dapat dilaksanakan secara konsisten dan berdasarkan azas-azas perkreditan yang sehat, maka diperlukan suatu kebijakan perkreditan yang tertulis. Berkenaan

${ }^{28}$ Bryan Saputra Tambuwun, Op. Cit., hlm. 196

${ }^{29}$ Skripsi Jony Hinaibaho, Op. Cit.,

30 Ramlan Ginting, Pengaturan Pemberian Kredit Bank Umum, disampaikan dalam diskusi "Aspek Hukum Perbankan, Perdata, dan Pidana Terhadap Pemberian Fasilitas Kredit Dalam Praktek Perbankan di Indonesia", Hotel Panghegar, Bandung, 2005, hlm. 3 
dengan hal tersebut, Bank Indonesia telah menetapkan ketentuan mengenai kewajiban bank umum untuk memiliki dan melaksanakan kebijakan perkreditan bank berdasarkan pedoman penyusunan kebijakan perkreditan bank dalam SK Dir BI No. 27/162/KEP/DIR, 31 Maret 1995. ${ }^{11}$ Berdasarkan SK Dir BI tersebut, Bank Umum wajib memiliki kebijakan perkreditan bank secara tertulis yang disetujui oleh dewan komisaris bank dengan sekurang-kurangnya memuat dan mengatur hal-hal pokok sebagai berikut: prinsip kehati-hatian dalam perkreditan; organisasi dan manajemen perkreditan; kebijakan persetujuan kredit; dokumentasi dan administrasi kredit; pengawasan kredit; atau penyelesaian kredit bermasalah. ${ }^{32}$

Kebijakan perkreditan bank dimaksud wajib disampaikan kepada Bank Indonesia. Dalam pelaksanaan pemberian kredit dan pengelolaan perkreditan bank wajib mematuhi kebijakan perkreditan bank yang telah disusun secara konsekuen dan konsisten. Pasal 11 UU Perbankan, memuat ketentuan bahwa Bank Indonesia sebagai Bank Sentral menetapkan ketentuan mengenai batas maksimal pemberian kredit atau pembiayaan berdasarkan prinsip Syariah, pemberian jaminan, penempatan investasi Surat Berharga, atau hal lain yang serupa, yang dapat dilakukan oleh bank kepada peminjam atau sekelompok peminjam yang terkait, termasuk kepada perusahaan-perusahaan dalam kelompok yang sama dengan bank yang bersangkutan. ${ }^{33}$

Pengertian BMPK menurut Muhamad Djumhana adalah suatu prosentase perbandingan batas maksimum penyediaan dana yang diperkenankan terhadap modal bank. ${ }^{34}$ Sedangkan pengertian BMPK menurut Pasal 1 angka 2 Peraturan Bank Indonesia Nomor 7/3/PBI/ 2005 tentang Batas Maksimum Pemberiatn Kredit Umum $^{35}$ adalah persentase maksimum penyediaan dana yang diperkenankan terhadap modal Bank. Tujuan ketentuan BMPK adalah untuk melindungi

${ }^{31}$ Ibid

${ }^{32}$ Ibid., hlm. 4

33 Gatot Supramono, Tindak Pidana Korupsi di Bidang Perbankan, Cetakan Pertama, Alumni, Bandung, 1997, hlm. 19 dikutip dari Bambang Catur PS, "Pengamanan Pemberian Kredit Bank Dengan Jaminan Hak Guna Bangunan”, Jurnal Cita bukum, Edisi No. 2 Vol I, (2014), hlm. 280

${ }^{34}$ Muhamad Djumhana, Hukum Perbankan di Indonesia, Cetakan Pertama, Citra Aditya Bakti, Bandung, 2000, hlm. 365

35 Selanjutnya disebut PBI BMPK 
kepentingan dan kepercayaan masyarakat serta memelihara kesehatan dan daya tahan bank, dimana dalam penyaluran dananya, bank diwajibkan mengurangi resiko dengan cara menyebarkan penyediaan dana sesuai dengan ketentuan BMPK yang telah ditetapkan sedemikian rupa sehingga tidak terpusat pada peminjam dan/atau kelompok peminjam tertentu. ${ }^{36}$

Penyediaan dana dalam kerangka BMPK tidak hanya berupa kredit, tetapi meliputi seluruh portofolio penyediaan dana yaitu penanaman dana bank dalam bentuk: kredit; surat berharga; penempatan; surat berharga yang dibeli dengan janji dijual kembali; tagihan akseptasi; darivatif kredit (credit derivative); transaksi rekening administratif (seperti guarantee, letter of credit, standby letter of credit); tagihan derivatif; potential future credit exposure; penyertaan modal; penyertaan modal sementara; bentuk penyediaan dana lainnya yang dapat dipersamakan dengan kredit sampai dengan penyertaan modal sementara. ${ }^{37}$

Seluruh portofolio penyediaan dana kepada pihak terkait dengan bank dapat dilakukan paling tinggi 10\% dari modal bank. Untuk penyediaan dana kepada seorang peminjam yang bukan merupakan pihak terkait dengan bank dapat dilakukan paling tinggi 20\% dari modal bank. Sementara, penyediaan dana kepada satu kelompok peminjam yang bukan merupakan pihak terkait dapat dilakukan paling tinggi 25\% dari modal bank. ${ }^{38}$ Peminjam digolongkan sebagai anggota suatu kelompok peminjam apabila peminjam mempunyai hubungan pengendalian dengan peminjam lain baik melalui hubungan kepemilikan, kepengurusan dan/atau keuangan. Sementara, pihak terkait adalah peminjam dan/atau kelompok peminjam yang mempunyai keterkaitan dengan bank sebagaimana dimaksud dalam Pasal 8 PBI BMPK. Bank wajib memiliki dan menatausahakan daftar rincian pihak terkait dengan bank dan dilaporkan kepada Bank Indonesia. ${ }^{39}$ Pengecualian diberlakukan terhadap perusahaan-perusahaan Badan Usaha Milik Negara (BUMN) dan/atau Badan Usaha Milik Daerah (BUMD) yang tidak diperlakukan sebagai kelompok peminjam sepanjang hubungan tersebut sematamata disebabkan karena kepemilikan langsung pemerintah Indonesia. Selain itu,

\footnotetext{
${ }^{36}$ Ramlan Ginting, Op. Cit., hlm. 5

${ }^{37}$ Lihat Pasal 1 angka 3 PBI BMPK

${ }^{38}$ Ramlan Ginting, Op. Cit., hlm. 5

${ }^{39}$ Ibid
} 
penyediaan dana bank kepada BUMN untuk tujuan pembangunan dan mempengaruhi hajat hidup orang banyak dapat dilakukan paling tinggi sebesar $30 \%$ dari modal bank. ${ }^{40}$

Pelanggaran BMPK adalah selisih lebih antara persentase BMPK yang diperkenankan dengan persentase penyediaan dana terhadap modal bank pada saat pemberian penyediaan dana. ${ }^{41}$ Sementara, pelampauan BMPK adalah selisih lebih antara persentase BMPK yang diperkenankan dengan persentase penyediaan dana terhadap modal bank pada saat tanggal laporan dan tidak termasuk pelanggaran BMPK sebagaimana dimaksud di atas. Penyediaan dana oleh Bank dikategorikan sebagai pelampauan BMPK apabila disebabkan oleh: penurunan modal bank; perubahan nilai tukar; perubahan nilai wajar; penggabungan usaha dan atau perubahan struktur kepengurusan yang menyebabkan perubahan pihak terkait dan atau kelompok peminjam; perubahan ketentuan. ${ }^{42}$

Jika terjadi pelanggaran BMPK dan atau pelampauan BMPK, Bank wajib menyusun dan menyampaikan rencana tindakan (action plan) untuk penyelesaiannya yang setidaknya memuat langkah-langkah untuk penyelesaian pelanggaran BMPK dan atau pelampauan BMPK serta target waktu penyelesaian sesuai dengan ketentuan dalam PBI BMPK. ${ }^{43}$ Bank yang menyampaikan action plan untuk pelanggaran BMPK setelah batas akhir waktu sampai dengan 14 hari kerja setelah batas akhir waktu tersebut, dikenai sanksi berupa kewajiban membayar sebesar Rp. 10.000.000,00 per hari kerja keterlambatan. Sementara, bank yang menyampaikan action plan untuk pelampauan BMPK setelah batas akhir waktu sampai dengan 14 hari kerja setelah batas akhir waktu tersebut, dikenai sanksi berupa kewajiban membayar sebesar Rp. 1.000.000,00 per hari kerja keterlambatan. Selanjutnya Bank juga diwajibkan untuk menyampaikan laporan pelaksanaan action plan masing-masing untuk pelanggaran BMPK dan pelampauan BMPK kepada Bank Indonesia paling lambat 14 hari kerja setelah realisasi action plan.

40 Ibid

41 Lihat Pasal 1 angka 6 PBI BMPK

42 Lihat Pasal 1 angka 7 PBI BMPK

43 Ramlan Ginting, Op. Cit., hlm. 6 
Bank yang menyampaikan laporan pelaksanaan action plan setelah batas akhir waktu sampai dengan 14 hari kerja setelah batas waktu tersebut, dikenai sanksi berupa kewajiban membayar sebesar Rp. 1.000.000,00 per hari kerja keterlambatan. ${ }^{44}$ Bank yang tidak menyelesaikan pelanggaran BMPK dan atau pelampauan BMPK sesuai dengan action plan setelah diberi peringatan 2 kali oleh Bank Indonesia dengan tenggang waktu 1 minggu untuk setiap teguran, dikenai sanksi administratif sebagaimana diatur dalam Pasal 52 ayat (2) UU Perbankan ${ }^{45}$, antara lain berupa: pencantuman anggota pengurus, pegawai bank, pemegang saham dalam daftar pihak-pihak yang mendapat predikat tidak lulus penilaian kemampuan dan kepatutan sebagaimana diatur dalam ketentuan Bank Indonesia yang berlaku; pembekuan kegiatan usaha tertentu, antara lain tidak diperkenankan untuk ekspansi penyediaan dana; dan atau larangan untuk turut serta dalam rangka kegiatan kliring. ${ }^{46}$ Selain itu, terhadap Dewan Komisaris, Direksi, pegawai bank, pemegang saham maupun pihak terafiliasi lainnya dapat dikenai sanksi pidana sebagaimana diatur dalam Pasal 49 ayat (2) huruf b, Pasal 50 dan Pasal 50 A UU Perbankan. ${ }^{47}$

Pelanggaran BMPK yang dilakukan oleh BCA maupun Bank Dagang Negara Indonesia melanggar Pasal 11 ayat (1) UU Perbankan dapat dikenai sanksi sebagaimana diatur dalam Pasal 49 ayat (2) huruf b dan Pasal 50 UU Perbankan, yang didalamnya terdapat ancaman pidana disertai denda.48 Namun dengan adanya klausula Release and Discharge di dalam perjanjian PKPS, maka pemegang saham dibebaskan dari aspek pidananya. Penuntutan secara pidana bagi para PSP yang memilih menyelesaikan utang BLBI melalui instrumen MSAA atau MRNIA berkaitan dengan Pasal 1853 KUHPerdata. ${ }^{49}$

Pasal 1853 KUHPerdata menyatakan bahwa kepentingan-kepentingan keperdataan yang terbit dari suatu kejahatan atau pelanggaran dapat diadakan

\footnotetext{
44 Ibid

${ }^{45}$ Lihat Pasal 52 UU Perbankan

46 Ibid

${ }^{47}$ Lihat Pasal 49 ayat (2) huruf b UU Perbankan

${ }^{48}$ Hassanuddin Rahman, Aspek-Aspek. Hukum Pemberian Kredit Perbankan di Indonesia, Cetakan Pertama, Bandung, Citra Aditya Bakti, 1995, hlm. 127

${ }^{49}$ Tri Widya Kurniasari, "MSAA dan MRNIA Bagi Recovery Dana BLBI: Sebuah Jalan Keluar atau "Jalan Untuk Keluar”, Jurnal Masyarakat dan Budaya, Edisi No. 1 Vol. 8, (2006), hlm. 64
} 
perdamaian namun perdamaian ini tidak menghalangi jawatan kejaksaan untuk menuntut perkaranya. Oleh karena itu, klausula Release and Discharge bukan merupakan pembebasan dari unsur pidana namun merupakan suatu penundaan penuntutan selama proses penyelesaian dan sarana mengurangi hukuman seandainya dapat menyelesaikan kewajibannya. Dengan demikian, maka tetap terdapat kemungkinan di kemudian hari untuk menuntut PSP Bank apabila terbukti menyalahgunakan utang BLBI. PSP Bank dapat dimintakan pertanggungjawaban secara pidana dengan berlandaskan Pasal 1853 KUHPerdata. Sehingga adanya klausula Release and Discharge dalam MSAA dan MRNIA tidak dapat berlaku lagi karena secara material telah batal demi hukum. Jadi bagi PSP bank tidak dapat lagi menggunakan klausula Release and Discharge untuk menghindar dati tanggung jawabnya. PSP bank yang terbukti melakukan pelanggaran BMPK dapat dimintakan pertanggungjawaban secara pidana maupun denda.

\section{Penutup}

Berdasarkan hasil penelitian, kajian, dan analisis seperti yang telah diuraikan pada bab-bab sebelumnya, maka di bagian ini penulis mengambil simpulan sebagai berikut: Pertama, perjanjian MSAA dan MRNIA yang mengikat antara BPPN dan PSP Bank penerima utang BLBI, merupakan suatu bentuk tanggung jawab pribadi pemegang saham utang BLBI. Klausula release and discharge dalam MSAA dan MRNIA secara formal telah memenuhi syarat perjanjian dalam Pasal 1320 KUHPerdata yaitu kata sepakat, kecakapan, suatu hal tertentu, dan kausa yang halal. Namun dalam pelaksanaannya, atau secara material perjanjian MSAA dan MRNIA yang mengandung klausula release and discharge tidak memenuhi syarat sah perjanjian yaitu kata sepakat dan kausa yang halal. Hal tersebut mengakibatkan perjanjian dapat dibatalkan serta batal demi hukum. Dengan demikian, maka release and discharge dalam MSAA dan MRNIA tidak memiliki kekuatan hukum yang mengikat perjanjian karena sejak pertama kali dibuat telah tidak sah, sehingga hukum menganggap bahwa perjanjian tersebut tidak pernah ada sebelumnya.

Kedua, perjanjian MSAA dan MRNIA yang mengandung klausula release and discharge secara material tidak memenuhi syarat sah perjanjian mengakibatkan 
perjanjian dapat dibatalkan serta batal demi hukum. Akibatnya perjanjian tidak memiliki kekuatan hukum yang mengikat sehingga hukum menganggap bahwa perjanjian tersebut tidak pernah ada sebelumnya. Dengan demikian, maka PSP Bank tidak dapat lagi berlindung dibalik klausula Release and Discharge dan kepadanya dapat dimintakan pertanggungjawaban sampai dengan harta pribadi sesuai dengan Pasal 3 ayat (2) UUPT. Selain itu PSP Bank yang terbukti malanggar BMPK dapat dilakukan penuntutan secara pidana terhadapnya.

Berdasarkan hasil penelitian, kajian, dan analisis seperti yang telah diuraikan pada bab-bab sebelumnya, maka di bagian ini penulis memberikan saran sebagai berikut pertama, Perlu penyempurnaan terhadap perjanjian MSAA dan MRNIA dengan kalusula release and discharge, karena perjanjian tersebut tidak sah. Sehingga, bagi para pihak yaitu BPPN dan PSP Bank seharusnya membuka peluang untuk dilakukannya revisi atas perjanjian ini, sehingga tidak ada pihak yang dirugikan lagi. Kedua, iika di kemudian hari ditemukan bukti-bukti baru yang menunjukkan PSP Bank melanggar isi perjanjian MSAA dan MRNIA yang memuat klausula release and discharge, maka release and discharge yang telah didapatkan secara otomatis batal demi hukum. Dengan demikian maka telah terbuka peluang bahwa bagi PSP bank yang ternyata melanggar perjanjian MSAA dan MRNIA untuk dilakukan perbaikan terhadap perjanjian tersebut, tak terkecuali penuntutan secara pidana apabila diperlukan.

\section{Daftar Pustaka}

\section{Buku}

Khairandy, Ridwan, Hukum Kontrak Indonesia dalam Perspektif Perbandingan (Bagian Pertama), Cetakan Kedua, Yogyakarta, FH UII Press, 2014.

, Hukum Perseroan Terbatas, Cetakan Pertama, Yogyakarta, FH UII Press, 2014.

, Kebebasan Berkontrak \& Pacta Sunt Servanda versus Iktikad Baik: Sikap yang Harus Diambil Pengadilan, Cetakan Pertama, Yogyakarta, FH UII Press, 2015.

Rahman, Hassanuddin, Aspek-Aspek Hukum Pemberian Kredit Perbankan di Indonesia, Cetakan Pertama, Bandung, Citra Aditya Bakti, 1995.

Satgas BLBI Bank Indonesia, Studi Keuangan Bantuan Likuiditas Bank Indonesia, Cetakan Pertama, Jakarta, Bank Indonesia, 2002. 
Satrio, J, Cessie, Subrogatie, Novatie, Kompensatie \& Percampuran Utang, Cetakan Kedua, Bandung, Alumni, 1999.

SS, Kusumaningtuti, Peranan Hukum dalam Penyelesaian Krisis Perbankan di Indonesia, Cetakan Pertama, Jakarta, Rajawali Pers, 2009.

Tim Humanika (Ed), BLBI: Megaskandal Ekonomi Indonesia, Cetakan Pertama, Jakarta, Humanika, 2001.

Zaini, Zulfi Diane, Independensi Bank Indonesia dan Penyelesaian Bank Bermasalah, Cetakan Pertama, Bandung, Keni Media, 2012.

\section{Jurnal}

Ginting, Ramlan Pengaturan Pemberian Kredit Bank Umum, disampaikan dalam diskusi "Aspek Hukum Perbankan, Perdata, dan Pidana Terhadap Pemberian Fasilitas Kredit Dalam Praktek Perbankan di Indonesia", Hotel Panghegar, Bandung, 2005.

Hertanto, Ari Wahyudi "Master Settlement and acquisition Agreement (MSAA) dan Master Refinancing and Note Issuance Agreement (MRNIA) dalam Perspektif Hukum Perdata (Suatu Tinjauan Singkat)", Jurnal Hukum dan Pembangunan, Edisi No. 4 Vol. 35 (2005).

Kurniasari, Tri Widya "MSAA dan MRNIA Bagi Recovery Dana BLBI: Sebuah Jalan Keluar atau "Jalan Untuk Keluar", Jurnal Masyarakat dan Budaya, Edisi No. 1 Vol. 8, (2006).

PS, Bambang Catur "Pengamanan Pemberian Kredit Bank Dengan Jaminan Hak Guna Bangunan", Jurnal Cita hukum, Edisi No. 2 Vol I, (2014).

Tambuwun, Bryan Saputra "Upaya Hukum Terhadap Deponering dalam Perspektif Hukum Progresif", Jurnal Lex Crimen, Edisi No. 2 Vol IV, (2015).

\section{Karya Ilmiah}

Hinaibaho, Jony. Penyampingan Perkara Pidana (Deponering) Berdasarkan Asas Oportunitas Oleh Jaksa Agung RI, Skripsi, Fakultas Hukum Universitas Sumatera Utara, Medan, 2010.

Sitorus, Lily Evelina, Release and Discharge Sebagai Alternatif Penyelesaian Masalah (Studi Kasus Kebijakan Penyelesaian BLBI), Tesis, Fakultas Ilmu Sosial dan Ilmu Politik Universitas Indonesia, Depok, 2009.

\section{Peraturan Perundang-undangan}

Kitab Undang-Undang Hukum Perdata

Undang-Undang Nomor 23 Tahun 1999 tentang Bank Indonesia

Undang-Undang Nomor 48 Tahun 2009 tentang Kekuasaan Kehakiman.

Undang-Undang Nomor 10 Tahun 1998 tentang Perubahan Indonesia. UndangUndang Republik Indonesia Nomor 7 Tahun 1992 tentang Perbankan 
Undang-Undang Nomor 40 Tahun 2007 tentang Perseroan Terbatas

Instruksi Presiden (Inpres) Nomor 8 Tahun 2002 tentang Pemberian Jaminan Kepastian Hukum Kepada Debitur yang Telah Menyelesaikan Kewajibannya atau Tindakan Hukum Kepada Debitur yang Tidak Menyelesaikan Kewajibannya Berdasarkan Penyelesaian Kewajiban Pemegang Saham (release \& discharge)

Peraturan Bank Indonesia Nomor 7/3/PBI/2005 tentang Batas Maksimum Pemberian Kredit Umum

\section{Internet}

Sie Infokum-Ditama Binbangkum, terdapat dalam https://www.jdih.bpk.go.id/ informasihukum/ReleasedDischarge.pdf diakses pada tanggal 30 Januari 2017.

Herlinda, Erna, Release and Discharge dalam Perspektif Hukum Keuangan Publik, e-USU Repository, 2004, terdapat dalam http://library.usu.ac.id/download/ fh/fh-erna3.pdf, diakses pada tanggal 3 Februari 2017. 